\section{Khmurova Viktoriia \\ Candidate of Economic Sciences, Associate Professor of Management Department Kyiv National University of Trade and Economics}

Yatsyshyna Klavdiia Candidate of Economic Sciences, Associate Professor of Management Department Kyiv National University of Trade and Economics

\title{
MECHANISM OF BUSINESS, AUTHORITIES AND LOCAL GOVERNMENT PARTNERSHIP
}

The increased interest in using the mechanism of public-private partnership in many countries of the world is due to the fact that its use allows the public sector to realize large-scale capital-intensive and resource-intensive projects in the field of socio-economic infrastructure at the expense of the optimum time and with the smallest cost. In the context of limited budget opportunities, the expansion of the practice of using the mechanism of public-private partnership can be a significant stimulus factor that will ensure the necessary growth rates of the country's economy. The main aspects of the mechanism of public-private partnership functioning are identified and described. The development of the modern cities economy is analyzed. The article analyzes the elements of the institutional environment, stimulating and / or restraining public-private partnerships on example of each given aspects.

Keywords: mechanisms of partnership between state and business, public-private partnership, economy of modern city, program of partnership development between business and authorities, partnership.

\section{ХмУРова В.В., Яцишина К.В. МЕХАНІЗМ ПАРТНЕРСТВА БІЗНЕСУ, ВЛАДИ І МІСЦЕВОГО САМОВРЯДУВАННЯ}

Статтю присвячено дослідженню механізму публічно-приватного партнерства. Підвищений інтерес до використання механізму публічно-приватного партнерства в багатьох країнах світу зумовлений тими обставинами, що його використання дає змогу державному сектору в оптимальні терміни та з найменшими витратами реалізовувати масштабні капіталомісткі та ресурсоємні проекти у сфері соціально-економічної інфраструктури. Таким чином, публічно-приватне партнерство дає змогу залучити додаткові фінансові ресурси. Проаналізовано об'єктивні підходи до розвитку підприємств приватного сектору під час їх взаємодії з іншими партнерами. Доведено необхідність формування механізму управління підприємством у складі публічно-приватного партнерства. В умовах обмежених бюджетних можливостей розширення практики застосування механізму публічно-приватного партнерства може бути значним стимулюючим чинником, який дасть змогу забезпечити необхідні темпи зростання економіки країни. Варто ініціювати притік приватних інвестицій в економіку, особливо в інфраструктурний розвиток. Це можливо здійснити за наявності бюджетних інвестицій у рамках реалізації публічно-приватного партнерства в рамках державних програм. Виділено та описано основні аспекти механізму функціонування публічно-приватного партнерства, а саме: організаційно-правовий, фрінансово-інвестиційний, техніко-організаційний та виробничо-господарський. Проаналізовано розвиток економіки сучасних міст, виявлено можливості використання механізму партнерства для бізнесу, влади і місцевої громади. Проаналізовано елементи інституційного середовища, стимулюючі та/або стримуючі публічно-приватне партнерство, на прикладі кожного з наведених аспектів. Визначено основні принципи, на яких варто будувати правильно організоване публічно-приватне партнерство. Визначено перспективи розвитку «розумних міст» на умовах залучення публічно-приватного партнерства.

Ключові слова: механізм партнерської взаємодії держави і бізнесу, публічно-приватне партнерство, економіка сучасного міста, програма розвитку партнерства бізнесу і влади, партнерство.

\section{Хмурова В.В., Яцышина К.В. МЕХАНИЗМ ПАРТНЕРСТВА БИЗНЕСА, ВЛАСТИ И МЕСТНОГО САМОУПРАВЛЕНИЯ}

Статья посвящена исследованию механизма публично-частного партнерства. Выделены и описаны основные аспекты механизма функционирования публично-частного партнерства, а именно: организационно-правовой, фринансово-инвестиционный, технико-организационный и производственно-хозяйственный. Проанализированы особенности развития экономики современных городов, выявлены возможности использования механизма партнерства для бизнеса, власти и местного самоуправления. В статье анализируются элементы институциональной среды, стимулирующие и/или сдерживающие фракторы публично-частного партнерства, на примере каждого из приведенных аспектов. Определены основные принципы, на которых стоит строить правильно организованное публично-частное партнерство. Определены перспективы развития «умных городов» на условиях привлечения публично-частного партнерства.

Ключевые слова: экономика современного города; публично-частное партнерство, механизмы партнерского взаимодействия государства и бизнеса, программа развития партнерства бизнеса и власти, партнерство.

Problem statement. The modern form of public administration requires the active participation of state and non-state institutions in developing new forms and rules to ensure fair, effective and accountable procedures in the development of society that would allow citizens to participate in the life of the country, to benefit from it. It is a combination of state and nonstate institutions that is promising and insufficiently studied on the use of the mechanism of public-private partnership.

Analysis of recent studies and publications. Among the scholars who carry out research on this issue, it is worth noting V. Heyets, B. Kvasnyuk, I. Zapatrina,
I. Pavlov, I. Lunin and others. However, so far, the principles of interaction between government, business and local self-government have not been formed in Ukraine.

The research purpose is to identify the stimulating and restraining elements in the mechanism of publicprivate partnership and the possibility of implementing «smart city» projects using these mechanisms.

Statement of the basic material and key research findings. Modern cities, in which intellectual, economic and human capital are concentrated, play an important role in the economic and social development of most countries of the world, they provide their 
competitiveness at the national and international levels. In modern cities, new development strategies are being born, new economic niches are opened, and centers of creativity, innovations and communications are created, which in aggregate are the driving force behind the development of individual territories and countries. Modern cities with a developed area of entrepreneurship not only develop, relying on market forces, they provide employment of the population, solve the social and environmental problems that arise, contribute to the establishment of local policies in the interests of this population.

The process of managing the development of publicprivate partnership institutes places a special place in the Strategy of Sustainable Development of Ukraine for the period up to 2030 [1]. In this connection, the necessity of developing the theory and methodology of providing partner interaction between public authorities, loca governments and business, science, education and civil society organizations is becoming more vital. Publicprivate partnership ensures the attraction of private capital to the implementation of strategically important infrastructure objects and thus contributes to reducing the budgetary burden in fulfilling the tasks for the social and economic development of the country. The real results of fruitful cooperation between the state and business are confirmed by an increase in the number of projects implemented under the conditions of public-private partnership.

The Law of Ukraine defines the meaning of the term public-public partnership as «cooperation between the state of Ukraine, the Autonomous Republic of Crimea, territorial communities in the person of the relevant state and local self-government bodies (state partners) and legal entities, except state and municipal enterprises, or individuals - entrepreneurs (private partners), which is carried out on the basis of the agreement in the order established by this Law and other legislative acts, and corresponds to the features of state-privately partnership defined by this Law» [2] Professor Zapatrina I.V considers public-private partnership as a regulation of contractual relations between the public sector, local governments and the private sector in the implementation of publicly significant projects [3]. Comparing the definitions that reveal the essence of the mechanism of partnership between the state and business, it is necessary to note the various semantic approaches of Ukrainian and foreign authors. So, if foreign authors in the definition of private-public partnership give priority to private business, then in Ukrainian practice there is the concept of public-private partnership, in which the priority is given to state authorities, which reflects the mentality and peculiarities of the existing relations. In essence, the transition to a partnership means a partial and, as a matter of time, the transfer to the private sector of certain functions of the state, permitted by law and executed by an agreement (contract).

The use of public-private partnership mechanisms allows: to increase the efficiency of using budget funds; to ensure more effective project implementation; realize a larger number of projects within a certain time frame.

Nevertheless, an analysis of the practice of implementing projects on the terms of publicprivate partnership shows that the negative effects on the development of public-private partnership are influenced by the contradictions that arise as a result of poorly elaborated legislation on publicprivate partnership projects in the social sphere at the state level, and above all in the communal economy. This is due to the fact that at the regional level, the legislation focuses mainly on the implementation of transport infrastructure objects, and on the ground mainly projects in social infrastructure and utilities are carried out on the principles of public-private partnership [4]. In addition to attracting private investment by type of economic activity, the role of public-private partnerships plays an important role in the development of private sector enterprises that are part of the partnership. This is due to the transaction exchange, carried out both within the public-private partnership, and at the external level. In the process of internal transaction exchange, the transfer of ownership of state assets to private sector enterprises takes place. Ownership of state assets, such as the right to use, the right to income, the right to manage, give the enterprise the opportunity to take part in the management of joint assets of a public-private partnership, in the distribution of income in general and to obtain additional income from the synergetic effect when using material- real assets in the process of implementing a joint project. This gives reason to believe that as a result of internal transactions for a private enterprise as a part of a public-private partnership, the legal basis for joint production, distribution of exchange and directly by the public-private partnership is created. It should also be borne in mind that the private enterprise, as part of the public-private partnership, retains its inherent ownership rights to its assets, which enables it to maintain autonomy and relative economic isolation in the terms of partnership and withdrawal from its membership. In the process of internal transactions, the enterprise transfers its ownership rights to the state, which should be defined as ownership rights of an organizational nature. These should primarily include the right to represent the enterprise in the external environment, the right to sign external contracts. By acquiring the ownership rights to use the assets of other members of the public-private partnership, the enterprise, along with obtaining additional income, which provides him with the growth of his own assets, receives the opportunity to ensure an increase in the assets of the enterprise as a whole more rapidly than in the increase of assets in its autonomous functioning. At the same time, with the use of mechanisms of public-private partnership: the quality of services provided is increasing; part of the risk is transferred to the private sector; more efficient use of resources is achieved. In order to understand whose interests prevail in the process of partnership interaction between business and government, in our opinion, it is necessary to more clearly identify the target installations of the subjects of this interaction, which are presented in Table 1.

Along with the internal transaction, an external transaction is carried out, which can be considered as an exchange process with environmental agents in the process of implementing infrastructure objects, as well as projects in the development of natural resources. Any exchange process with the external environment threatens the enterprise with an increase in transaction costs, but the public-private partnership institute provides some degree of reduction in the transaction costs of enterprises that are part of it. Transaction costs include information costs relating to the search for information, analysis and storage; expenses incurred in conducting negotiations, as well as costs associated with conducting internal control over the activities of partners, the cost of protection from third parties in order to protect 
Possibilities of public-private partnership for the state and business

Table 1

\begin{tabular}{|c|c|c|}
\hline № & Goals of the state & Business Goals \\
\hline 1 & $\begin{array}{l}\text { Increasing the living standards of the population, } \\
\text { «human capital» development }\end{array}$ & $\begin{array}{l}\text { Expansion of opportunities for capital reproduction, penetration } \\
\text { of its previously unavailable sectors of the economy }\end{array}$ \\
\hline 2 & $\begin{array}{l}\text { Overcoming structural imbalances in the strategy of } \\
\text { economic growth }\end{array}$ & Participation in projects implementation using budget funds \\
\hline 3 & $\begin{array}{l}\text { Supporting the competitiveness of business in the } \\
\text { domestic and foreign markets }\end{array}$ & $\begin{array}{l}\text { Possibility of obtaining state guarantees and lending projects of } \\
\text { social significance by foreign financial organizations }\end{array}$ \\
\hline 4 & $\begin{array}{l}\text { Improvement of the services quality provided to the } \\
\text { population, which are within the competence of the state }\end{array}$ & $\begin{array}{l}\text { Reducing the tax burden, providing benefits and preferences } \\
\text { for businesses }\end{array}$ \\
\hline 5 & $\begin{array}{l}\text { Implementation of large infrastructure projects that } \\
\text { could not be realized due to budget deficits or other } \\
\text { reasons }\end{array}$ & $\begin{array}{l}\text { Participation in profitable realization and development of state } \\
\text { property objects. Preservation of strategic control over created } \\
\text { assets }\end{array}$ \\
\hline 6 & $\begin{array}{l}\text { Reducing disproportions in the socio-economic } \\
\text { development of the regions }\end{array}$ & $\begin{array}{l}\text { Facilitation of obtaining licenses, permits, conclusions of } \\
\text { supervisory bodies }\end{array}$ \\
\hline 7 & $\begin{array}{l}\text { Integration of domestic enterprises into the world } \\
\text { economy }\end{array}$ & Creating a positive image of companies \\
\hline 8 & $\begin{array}{l}\text { Ability to use managerial experience, skills and } \\
\text { professionalism of private business, introduction of } \\
\text { advanced management methods }\end{array}$ & $\begin{array}{l}\text { Developing a dialogue between government and business in all } \\
\text { sorts of spheres, stimulating innovative thinking, finding new } \\
\text { and promising methods of interaction }\end{array}$ \\
\hline
\end{tabular}

Source: built by the author on the basis of [3;4]

members of the partnership from economic pressure and claims. All these types of transaction costs are borne by the state structures, the partners, or the publicprivate partnership is the realization of the interests of its members. The development of the company as part of the public-private partnership is carried out through an active internal transaction exchange, which ensures the transfer of rights to use, management of public and private assets, as well as rights to distribute common income in addition to the rights to own assets of the enterprise. The main directions of enterprise development in the system of public-private partnership are production-technical, technological; innovative; socio-economic; organizational and managerial; communicative. Industrial and technical, technological development of the enterprise requires modernization of the production and technical base of the enterprise at the expense of its own sources, as well as at the expense of capitalization of the share of the total income received by the enterprise as part of the partnership. The consequence of industrial, technical and technological development is the flexibility of production, adaptability to the rapid change in the needs of customers, achieved through access to the use of technologies of other enterprises - partners of the partnership.

Innovative development of the enterprise is characterized by adaptation of the enterprise to work in a new technological way, as well as in the innovative sector of the economy. This necessitates the import of knowledge into an organization, requires systematization of knowledge and development of the intellectual capital of the organization, and in some cases the use of knowledge as an economic factor of production. The socio-economic development of the enterprise is based on increasing the efficiency of production as a result of the scale effect, as well as participation in the business processes of the enterprise in conjunction with other members of the partnership, which enables them to engage in new technologies of other enterprises. As a result, the competitiveness of the company and its employees increases as the internal mechanism of income growth, profitability and saving on cost reduction is realized. It should be noted that the economic and social-labor relations in the enterprise are improved in connection with the development of cooperation of employees, as well as the introduction of the principles of social justice and social responsibility.
Organizational and managerial development of the enterprise within the partnership may be as a result of the formation of an enterprise management model based on the principles of public management and management of commercial enterprises, which allow using active and passive forms for attracting employees to enterprise management and realizing control functions of public management.

The communicative development of the company is aimed at improving information and communication technologies, as well as their tools in the interaction of the enterprise with the agents of the environment and business partners. The communicative development of the enterprise allows it to enter industrial networks, as well as use different forms of cooperation with other business entities. The development of enterprises within the public-private partnership is influenced by external and internal factors. As external factors can be named the cooperation of employees in the partnership; accumulation of knowledge and formation of intellectual capital of the enterprise as a result of import and transit of knowledge in the interaction of the enterprise with other members in the partnership. The internal factors should first of all include the created economic potential of the enterprise; the experience of the enterprise in the partnership, the interaction management of the partners. The mechanism for managing the development of the enterprise as part of the partnership can be considered as the implementation of the functions of process and project management, which can affect the specified directions of enterprise development. Managing the technology of project management, the management of the company will be able to determine the relationship with external customers, eliminate violations in scheduled tasks, reduce the losses that arise. Project management tools allow using the technology of key changes during the implementation of the project, linking the business interests of the enterprise with the project being implemented. At the same time, project management will make it possible to change the existing organization of production and create conditions for the choice of new directions in the enterprise and the change of technology for the production of new products. As a result of using project management at the enterprise, the preconditions for improving the specialization of the main activity, expansion of 
new types of specialization and development of new types of production activity are created. Particularly large role of project management for socio-economic and organizational and managerial directions of enterprises development within the partnership, as the organizational structure of the company changes and the possibilities of democratization in the management of the enterprise are expanding. The use of process management leads to a change in the format of the participants' interaction in business processes.

An enterprise within a public-private partnership gets the opportunity to study the flow simulation of the interconnected and interrelated business processes and monitor their implementation. In general, it can be noted that process management facilitates the development of an enterprise in such areas as industrial, technical, technological, socio-economic, organizational and managerial. In addition to project and process management, companies within the public-private partnership have the opportunity to use elements of public management and management of commercial enterprises in the enterprise management system, which allows to intensify control in various forms and, above all, extend the powers of public control, public audit and public supply. Public management helps to build business processes in the enterprise, determine the criteria and directions of enterprise development in the future, the choice of less costly forms of advanced training and improve the competence of enterprise's employees. Public management also provides enterprise adaptation to the external environment, which is especially important for him after leaving the partnership, as it enables the integration into production networks. The analysis of the enterprise management system as part of the public-private partnership shows that management of commercial organizations creates conditions for the development of the enterprise development strategy in the future, provides technical modernization of production, identifies the strategic advantages of the enterprise, based on how these benefits will be sufficient for the enterprise in the future [4]. The combination of public management and management of commercial organizations allows to realize the principles of rationality and efficiency of production and economic activity in the company's activities; orientation to public values in the production of services and in the implementation of infrastructure projects; the principle of excellent competitive advantages of the enterprise, providing it with a certain margin of safety in production and economic activity and the opportunity to take a favorable position in the market when leaving the partnership; the principle of stabilization of the production and economic activity of the enterprise and the successful interaction with partners and employees of the enterprise. In the implementation of projects involving public-private partnerships, the principle of social responsibility plays an important role. Social responsibility is considered as a collective social responsibility of business partners in conjunction with the collective responsibility of the state as part of the partnership. Thus, the social responsibility of the public-private partnership should be considered as a synthesis of socio-economic and political aspects in the activities of the state and business, which express the involvement in the national needs, aspirations and interests of the people and the country [4].

According to experts, about $70 \%$ of the infrastructure services of territorial units in England are implemented on the basis of models of publicprivate partnership. Experts expect a significant increase in such projects worldwide, for example, in countries with strong urbanization trends and a major disadvantage of public capital (Latin America and Africa) or in reformed countries of Eastern Europe, where decentralization at the state level leads to the definition of new tasks at the regional or communal levels without adequate provision of its capital [3].

Practically all modern cities are faced with the problems of establishing effective mechanisms of interaction between the state, business and the population, the whole thing is how local administrations react to them, how they integrate their efforts and efforts of local community, business for their successful solution.

It should be formulated key problems that impede the effective interaction of the population, business and government: the high volatility of the economic and financial situation in the country; lack of a unified system of governance and institutions capable of coordinating the process of interaction; the unwillingness of the authorities and business to engage in partnerships and implement public-private partnership projects; a high level of bureaucracy and corruption, which hinders the establishment of trust and constructive relations with entrepreneurs; poorly developed social orientation of business, its interest in solving not only its private but also local problems; lack of right practice; the passivity of the territorial administration bodies to initiate and jointly promote projects on the terms of public-private partnership.

It should be noted that many of the listed problems are successfully addressed in modern cities seeking to break the crisis. Adopted by the territorial management bodies of the program for developing business and government partnerships include modern mechanisms that allow building sustainable trust in power, business and government authorities in the cities. Transformation of the modern cities economy can be associated with the transition to a new state that cannot be achieved without generators of innovation, new knowledge. Only by relying on it, it can be got a new look and opportunity to discuss such a city environment as «intelligent city», «intellectual», «educational», «self-developing», «sustainable». It is no accident that the terms «smart city» and «intellectual territory» were introduced in the early 1990's when Singapore became an «intellectual island», while Toronto and the Silicon Valley were «smart cities» and "smart valleys». It should be noted that the advancement of urban technological transformation did not immediately catch up with lagging cities, the specificity (industrial orientation) of which negatively affected the economy and social transformations, because they did not pay much attention to innovations. The theory of «living cities» is presented in the works of Jane Jacob [5] and other authors whose research was devoted to the strategies of urban planning.

In developing strategy of its development, «smart cities» are not only developed through market forces or local self-government, they affect employment, production growth, using a wide range of tools in a globalized environment. Such cities with limited types of production are forced to exhibit creativity and dynamics, to anticipate events, to mobilize local intellectual, economic, social and political resources in a single management process that allows them to realize the strategy of their socio-economic development and to provide competitive advantages.

It should be distinguished the following areas for improving the interaction of the population, business and government in «smart cities»:

1) formation of institutional conditions, acceptable for all subjects of public-private partnership interaction; 
2) creation of stable and attractive conditions for investment activity in "smart cities»;

3 ) support and guarantees of the state to partners from the private sector;

4) development and institutionalization of a single concept of development of public-private partnership in the country;

5) use of business associations and public organizations to conduct dialogue with the state on the problems of effective interaction of the population, business and government;

6) creation of "centers of competence» as organizational structures for initiating and managing projects of public-private partnership in «smart cities»;

7) organization of informational and educational work in the framework of public-private partnership promotion.

Conclusions from the conducted research. Summing up, it should be concluded that the mechanism for managing the development of the enterprise in the system of public-private partnership is provided at the expense of regulatory influence on the choice and implementation of the directions of enterprise development with the help of tools and methods of project management and process management. The operation management of the enterprise is implemented on the principles of commercial organizations management and public management. It is the emphasis to use the elements of commercial organizations management and public management, which contributes to the orientation of industrial and economic activity of the enterprise on the public values, the identification and development of its own excellent competitive advantages, which ensure the stabilization of its main activities, as well as the development of new types of production and the opportunity to take the leading position on market after leaving the partnership.

\section{REFERENCES:}

1. Stratehii staloho rozvytku Ukrainy na period do 2030 roku [Strategies for sustainable development of Ukraine for the period up to 2030]. Retrieved from: http://www.ua.undp.org/content/dam/ ukraine/docs/SD\%20Project_Ukraine_version\%203-2-1.pdf (accessed 18 March 2019)

2. Zakon Ukrainy Pro derzhavno-pryvatne partnerstvo [Law of Ukraine on public-private partnership]. Vidomosti Verkhovnoi Rady Ukrainy (VVR), 2010, № 40, st. 524). Retrieved from: https://zakon. rada.gov.ua/laws/show/2404-171_accessed 18 March 2019)

3. Zapatrina I. Publichno-chastnoye partnerstvo kak novaya ideologiya razvitiya mirovogo soobshchestva [Public-private partnership as a new ideology for the development of the world community]. Retrieved from: www.ukrppp.com/present/doklad_ astana zapatrina.doc,2011 (accessed 18 March 2019)

4. Bill Khatchison (2013-2014). Naskolko umen vash «umnyy gorod» i pochemu eto dolzhno vas bespokoit? BRICS. Business magazine, 42. Retrieved from: http://eurasianews.md (accessed 18 March 2019)

5. Dzheyn Dzhekobs (2008). Ekonomika gorodov [City Economy]. Moskva : Izdatelstvo : Kulturnoye naslediye. [in Russian] 